\title{
CHANGES IN PLACENTAL MORPHOLOGY AND THEIR ASSOCIATION WITH EMBRYONIC SKIN DEVELOPMENT
}

\author{
Jurijs Markovs ${ }^{1}$, Agate Galuza ${ }^{1}$, Ivars Melderis ${ }^{2}$, \\ and Džanna Krūmiṇa ${ }^{1,3}$, Gundega Knipše ${ }^{1,3, \#}$ \\ 1 Faculty of Medicine, University of Latvia, 4 O. Vācieša Str., Rīga, LV-1004, LATVIA \\ ${ }^{2}$ Children's Clinical University Hospital, 45 Vienības gatve, Rīga, LV-1004, LATVIA \\ ${ }^{3}$ Institute of Cardiology and Regenerative Medicine, 13 Pilsoṇu Str., Rīga, LV-1002, LATVIA \\ \# Corresponding author, gundega.knipse@lu.Iv
}

Communicated by Vija Kluša

\begin{abstract}
Histogenesis and organogenesis in mammals normally transpires in a hypoxic environment. Oxygen diffusing capacity is dependent on diffusion distance, which may vary with the thickness of placental barrier and with the level of tissue vascularity. Since the epidermis is avascular, its development fully depends on dermal blood vessels. Despite the large number of studies focusing on uteroplacental circulation and embryogenesis, it is clear that the current knowledge of how placental changes in pregnancy contribute to skin development is incomplete. The aim of this study was to evaluate the association between structural changes in the placental barrier and development of the integumentary system, with special reference to dermal angiogenesis. The study included specimens of six embryos and ten foetuses from 5 to 24 developmental weeks, and 21 specimens of placental tissue 6-40 weeks gestational age. The panel of antibodies used was S100, SMA, CD31, CD34, AE1/AE3 (PCKT), CKRT7, CD 56 and hCG. During the first trimester, maternal blood flow to the placenta appears to be initially restricted by trophoblast plugs. Natural killer cells appear in great abundance in subendothelium of decidual blood vessels, potentially stimulating extensive angiogenesis. By the end of the first trimester, new capillary beds organise to supply the developing epidermal derivatives. During the second trimester, the placental barrier becomes progressively thinner, and uteroplacental circulation is established due to dissolution of endovascular trophoblast plugs. Progression of the formation of skin appendages, hypodermal adipose tissue, demarcation of papillary and reticular dermis, and keratinisation of interfollicular epidermis in the second trimester strongly accompanies the dermal angiogenesis and placental maturation.
\end{abstract}

Key words: embryogenesis, placental barrier, integumentary system.

\section{INTRODUCTION}

Mammalian embryogenesis takes place in environments that are physiologically hypoxic. Not only the preimplantation phase (fertilisation, cleavage, compaction, blastocystogenesis, and hatching), but also histogenesis and organogenesis unfolds again under physiological hypoxia (Huppertz et al., 2009). Consequently, oxygen availability is an important factor in determining the rate of embryogenesis. The placenta provides oxygen and nutrients to the growing embryo/foetus. As the primary interface between mother and embryo/foetus, the placenta serves for four main functions, including anchoring of the conceptus to the uterus, transport of nutrients, oxygen and waste products, hormone secretion, and immunological protection of the genetically foreign embryo/foetus. One of the most remarkable processes associated with the establishment of pregnancy is the process of decidualisation (Lima et al., 2014). This transformation of a stromal fibroblast to a fully differentiated decidual cell is required for controlled trophoblast invasion, protection of conceptus from maternal immune rejection, and placental separation. The decidua is also a rich source of detoxificating enzymes. Many placental functional changes occur that accommodate the increasing metabolic demands of the developing foetus throughout gestation. Extravillous trophoblast cells migrate into the decidua 
and remodel uterine arteries (Chen et al., 2012). This facilitates blood flow to the placenta via dilated, compliant vessels, unresponsive to maternal vasomotor control. A role of NK cells in vessel remodelling is also beginning to be elucidated (Fraser et al., 2015).

The skin's outermost layer (epidermis), composed of keratinised stratified squamous epithelium, derives from embryonic surface ectoderm. It is avascular, receiving oxygen and nutrients from vessels in the underlying dermis. Therefore, the development of the epidermis depends on dermal angiogenesis. The dermis is a highly vascularised structure, and contains a superficial and deep plexus of arterioles and venules (Gunin et al., 2014). The formation of the vascular network supplying the skin occurs in early embryonic life, but further development of the vascular plexuses is not well studied (Martin et al., 2014).

The cardiovascular system is extensively remodelled throughout embryogenesis and the hematopoietic system also undergoes dramatic changes, especially with regard to erythropoiesis (Baron et al., 2012). Although the association between dermal vasculogenesis and the development of epidermal derivatives has been established, there are only a few studies concerning relationship between the abovementioned events, remodelling of placental blood vessels, and hematopoietic ontogeny (Coolen et al., 2010; Stanek, 2013). Therefore, in this study we attempt to find associations that are related to the chronology of integumentary system development, maturity changes in the placenta, and changes in embryo/foetus erythropoiesis.

\section{MATERIALS AND METHODS}

We examined six embryos and ten foetuses at the age of 5 to 24 developmental weeks and placental tissue from the embryological collection of the Department of Anatomy and Histology, University of Latvia, Rīga, Latvia. Gestational age was estimated from the crown rump length of the embryo/foetus. Taking into account variations in the structure of skin on different anatomic sites and different growth rate of the skin derivatives, we investigated regional peculiarities of dermal vascularity. For this purpose, samples of an archival collection of skin of the upper limb bud, lower jaw, finger palmar surface, dorsal and lateral surface of the trunk, the forearm of the embryo/foetus, and of the nail were stained with haematoxylin-eosin, Masson's Trichrome and immunostained with antibodies against S-100 protein, smooth muscle actin (SMA), CD31, and CD34. Firsttrimester human placental tissue of 6-12 weeks gestational age was obtained from ten individuals after elective termination of uncomplicated pregnancies.

Second-trimester human placental tissue of 15-19 weeks gestational age was obtained from five patients with spontaneous pregnancy loss. Likewise, six samples of full term placentas (37-40 weeks) of uncomplicated pregnancies and normal deliveries were entered in this study. Full thickness blocks were taken from the centre of the placenta. Placental tissue was sectioned, subsequently stained with haematoxylin-eosin and immunostained with antibodies against pan-cytokeratin AE1/AE3 (PCKT), cytokeratin 7 (CKRT7), CD 31, CD 34, CD 56 and human chorionic gonadotropin (hCG) to allow identification of cytotrophoblast, syncytiotrophoblast, and extravillous trophoblast (PCKT), extravillous trophoblast (CKRT7), NK cells (CD56), human chorionic gonadotropin (hCG), blood vessels (CD34), and blood vessels and macrophages (CD31) (McKenney et al, 2001). Anti-AE1/AE3 (PCKT) - Monoclonal Mouse, X-H Cytoker, Clone AE1/AE3, RTU; anti-cytokeratin 7 (CKRT7) Monoclonal Mo a Hu Cytokeratin 7, Clone OV-TL 12/30, RTU; anti-CD 31 - Monoclonal Mo a Hu CD31, Endothelial Cell, Clone JC70A, RTU; anti-CD 34 - Monoclonal Mo a Hu CD34 Class II, Clone QBEnd 10, RTU; anti-CD 56 Monoclonal Mo a Hu CD56, Clone 123C3, RTU and antichorionic gonadotropin (hCG) - Polyclonal Rb a Hu Chorionic Gonadotropin, RTU were purchased from DAKO, Glostrup, Denmark.

Due to the ethical and legal restraints on studies of human embryo we received a limited number of embryos at different developmental stages, and therefore the statistical analysis was not performed as in some current studies (Weiss et $a l .$, 2016). The proposal for this investigation was approved by the Ethics Committee, Institute of Cardiology and Regenerative Medicine, Rīga, Latvia.

\section{RESULTS}

Changes in placental morphology. In the earliest specimen available (six weeks after conception) the surface of the placental villi was composed of an outer syncytiotrophoblast and complete inner layer of cytotrophoblast. Most villi contained loose mesenchyme together with centrally located blood capillaries. Our studies revealed that Hofbauer cells in the matrix have somewhat rare occurrence. At the distal tips of the villi the cytotrophoblast grows out and continues into cell columns. The intermediate (extravillous) trophoblast migrates from the trophoblastic columns and invades decidual tissue.

The present work showed that near the end of the $6^{\text {th }}$ week, the syncytiotrophoblastic cover of the basal plate becomes locally replaced by Rohr's fibrinoid. Underneath the fibrinoid several layers of fully differentiated decidual cells are located. Within this layer of the decidua the straight portions of uterine glands and dilated blood vessels were also apparent. By the $12^{\text {th }}$ week, only occasional fragments of the endometrial glands were seen. From six weeks of gestation onwards, vascular endothelial and smooth muscle cells were lost from the spiral arteries and were replaced by extravillous trophoblast cells and fibrinoid. The lumen of the remodelled vessel was dilated. The endothelium temporarily disappeared, although it was restored by the $37^{\text {th }}$ week of pregnancy (Fig. 1A). In our collection early vascular alterations in myometrial arteries, such as endothelial vacuolation and some swelling in smooth muscle cells, were also observed. In the $7^{\text {th }}$ week of gestation, the trophoblastic plugs 


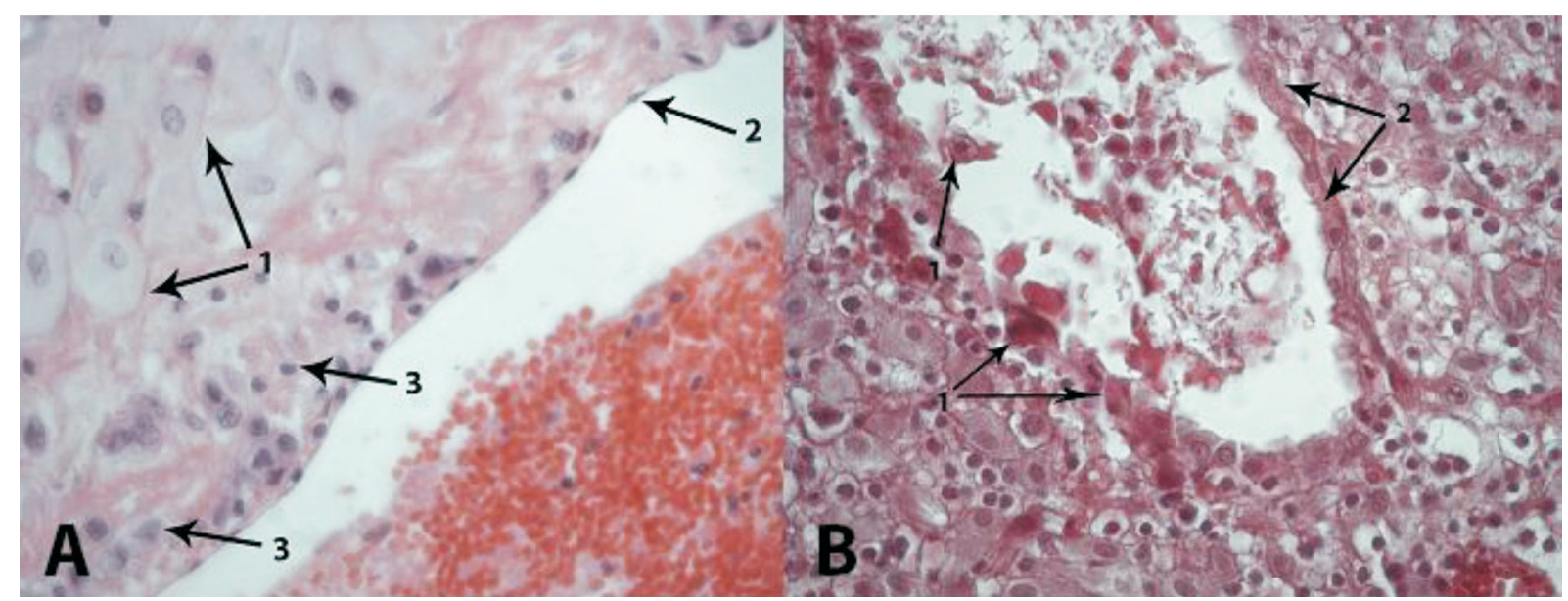

Fig. 1. A: Basal plate at 37 weeks of pregnancy contains remodelled vessel with extravillous trophoblast embedded in the fibrin wall. 1, decidual cells; 2 , endothelium; 3, extravillous trophoblast. Haematoxylin-eosin stain, 40×. B: Endoglandular trophoblast invades and replaces the epithelium of uterine glands. 1, endoglandular trophoblast; 2, uterine gland. Haematoxylin-eosin stain, 20x.

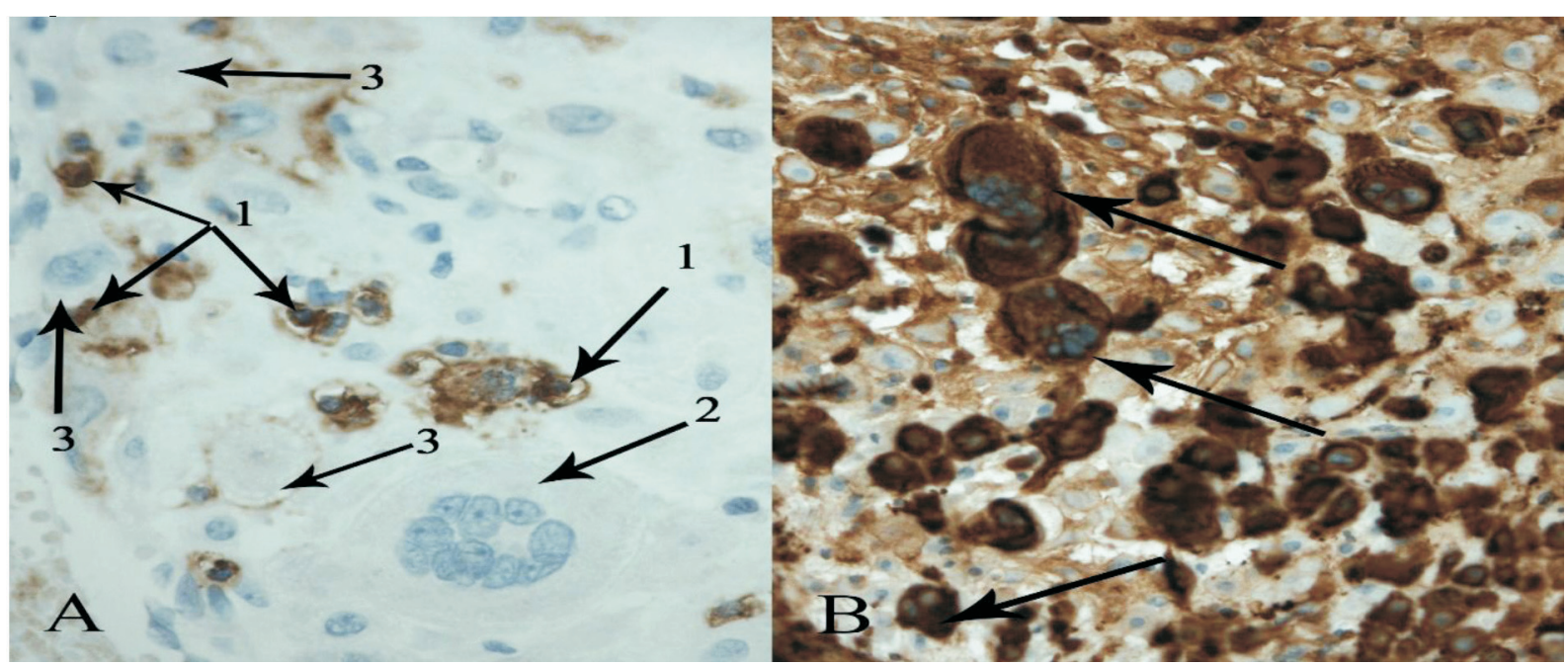

Fig. 2. A: Basal plate at 18 weeks of pregnancy contains clusters of CD-56-positive NK cells (1) in the direct vicinity of multinucleate trophoblastic giant cell (2) and extravillous trophoblast cells (3). CD56 immunohistochemical staining, 40×. B: In immunohistochemical staining CKRT7-positive extravillous trophoblast cells (arrowed) within the basal plate at 18 weeks. CKRT7 immunohistochemical staining. 20x.

in the spiral arteries obstructed maternal blood flow into the intervillous space and prevented flow until the end of first trimester of pregnancy. Simultaneously, uterine glands were invaded and opened by endoglandular extravillous trophoblast towards the intervillous space of the placenta. It must be pointed out that the partial replacement of glandular epithelial cells by endoglandular trophoblast also occurred (Fig. 1B). During decidualisation, the endometrial stroma increased in quantity. It contained a substantial population of NK cells. These cells were identified based on cell and nucleus size, nuclear/cytoplasm ratio, and expression of CD56. NK cells were frequently seen together with the migrating extravillous trophoblast and also in close proximity to endothelium of decidual vessels (Fig. 2). Areas of dense NK cell infiltration contained venules with plump endothelium, which resembled the endothelium of the high endothelial venules (HEV) (Fig. 3A).

By the $9^{\text {th }}$ week of gestation, the nearly uniform large villi achieved the reticular stroma and centrally placed blood vessels lacking media of typical immature intermediate villi could be recognised. During the second trimester, more richly vascularised and slender mature intermediate villi developed (Fig. 3B). The blood capillaries established contact with villous trophoblast, and the syncytiotrophoblastic layer became gradually thinner. It is important to note that at the beginning of the mid trimester of pregnancy, some mature intermediate villi exhibited the first signs of early terminal villi formation. In such localised areas some cytotrophoblast cells disappeared and foetal capillaries came into close contact with the syncytiotrophoblast. Villous cytotrophoblast cells were easily identified in the second trimester, but in the third trimester they were not seen in abundance. It was shown that Hofbauer cells increased in number from the first to second semester. Placental villous maturation was maximal in the third trimester, with an abundance of terminal villi in the term placenta. This type of villi had fused foetal capillaries with syncytiotrophoblast (vasculosyncytial membranes) and syncytial knots.

Skin maturation and development of dermal vasculature. By the $5^{\text {th }}$ week, embryonic skin consisted of a single layer of ectodermal cells and a relatively thick mostly avascular dermal mesenchyme in most regions of the embryo. 


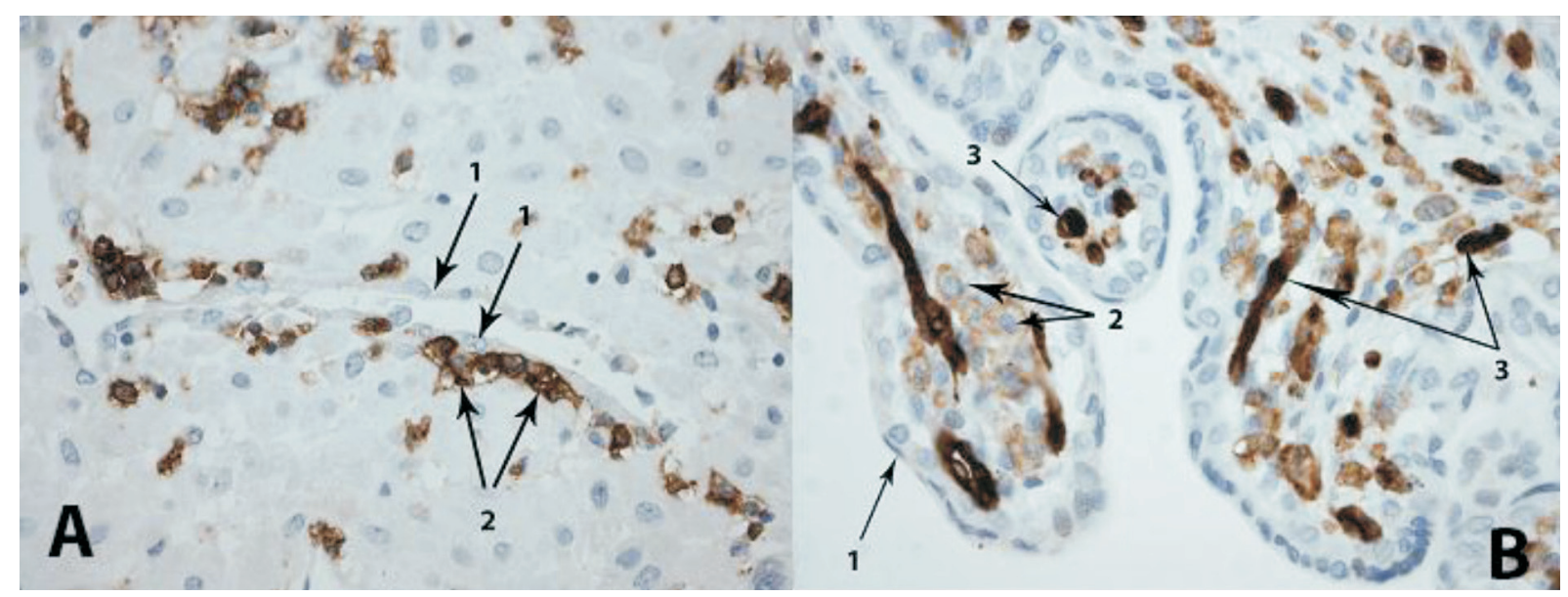

Fig. 3. A: Immunohistochemical stain reveals CD-56-positive NK cells accumulation beneath the endothelium of the HEV-like vessel. 1, endothelium; 2, NK cells. CD56 immunohistochemical staining, 20×. B: Mature intermediate villi with attenuated syncytiotrophoblast and abundant Hofbauer cells from placenta at 19 weeks. Capillaries are fairly peripherally located. 1, syncytiotrophoblast; 2, Hofbauer cells; 3, capillary. CD31 immunohistochemical staining, 20×.

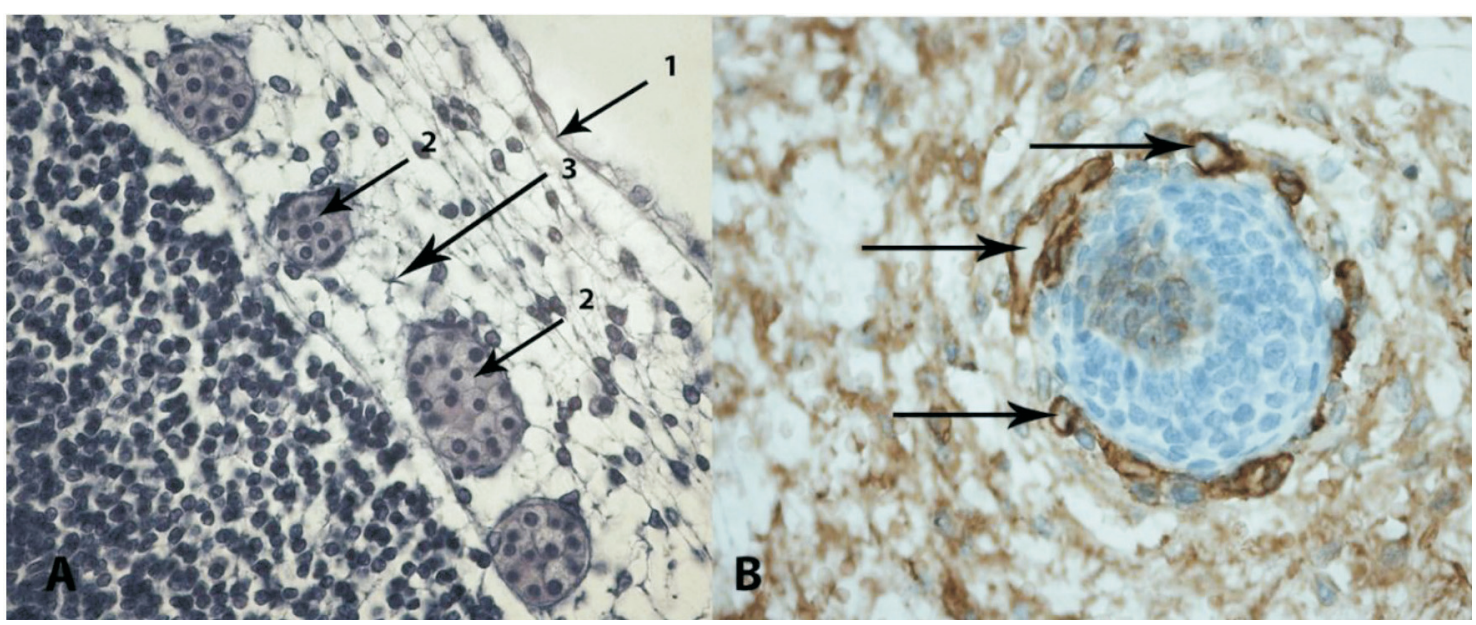

Fig. 4. A: The skin of the mid-back of the 5 weeks old embryo. Sinusoidal vessels filled with the nucleated RBC in the area of presumptive leptomeninx. 1, one-layered epidermis; 2, sinusoidal vessels; 3, presumptive leptomeninx. Haematoxylin-eosin stain, 20x. B: The hair follicle from the forearm of the 17 weeks old embryo. An arrow points to the blood vessels embedded in the connective tissue sheath. CD34 immunohistochemical staining. $20 \times$.

At the end of the $6^{\text {th }}$ week, embryonic skin was already covered by a two-layered (basal layer and periderm) epidermis. The blood vessels in the dermis originated as capillaries, which sprouted from the existing small vessels in the presumptive hypoderm. These vessels in turn grew out from the vascular plexuses, which supply with blood the developing subcutaneous organs, such as muscles or spinal cord. Initially the density of the dermal capillary network of the skin of the lateral surface of the trunk was very low. Simultaneously, the presumptive dermis overlying spinal cord contained no blood vessels. (Fig. 4A). The first identifiable primordial hair follicles appeared at about nine weeks in areas that will eventually become the eyebrows, upper lip and chin. It should be pointed out that growing hair follicles were surrounded by blood vessels that arose from the deep vascular plexus, but interfollicular areas remained significantly less vascularised (Fig. 4B).

Until the $6^{\text {th }}$ and $7^{\text {th }}$ weeks of gestation, all embryonic erythrocytes were nucleated and located in a poorly developed dermal vascular framework. Mesenchymal cells differentiated into fibroblasts, producing delicate collagen bun- dles by the $12^{\text {th }}$ week of gestation. As gestational age advanced, mature collagen bundles appeared, and definite papillary and reticular dermis became recognisable in the $15^{\text {th }}-16^{\text {th }}$ week. It is important to emphasise that by the end of the $16^{\text {th }}$ week, the major vascular organisation of the foetal dermis was established and dermal arterioles and venules could be distinguished. Ascending arterioles and descending venules were paired as they connected the superficial and deep plexuses (Fig. 5A). Postcapillary (pericytic) venules became the predominant type of vessels in the upper part of the dermis (Fig. 5B). Red blood cells (RBC) moving through these blood vessels were mostly enucleated. By the $11^{\text {th }}$ week, the epidermis was a smooth thin layer of epithelial tissue made up of three layers: the basal layer, the intermediate layer, and the periderm. At this stage the development of the primary epidermal ridges (PER) began. PER proliferated rapidly and projected into the dermis. Merkel cells that were globular in shape were seen in the finger palmar PER around the $16^{\text {th }}$ week. In about the $13^{\text {th }}-14^{\text {th }}$ week, eccrine sweat gland anlagen appeared along the apices of PER on the palms. S-100 positive myoepithelial cells and clear cells in the secretory portion of eccrine sweat 


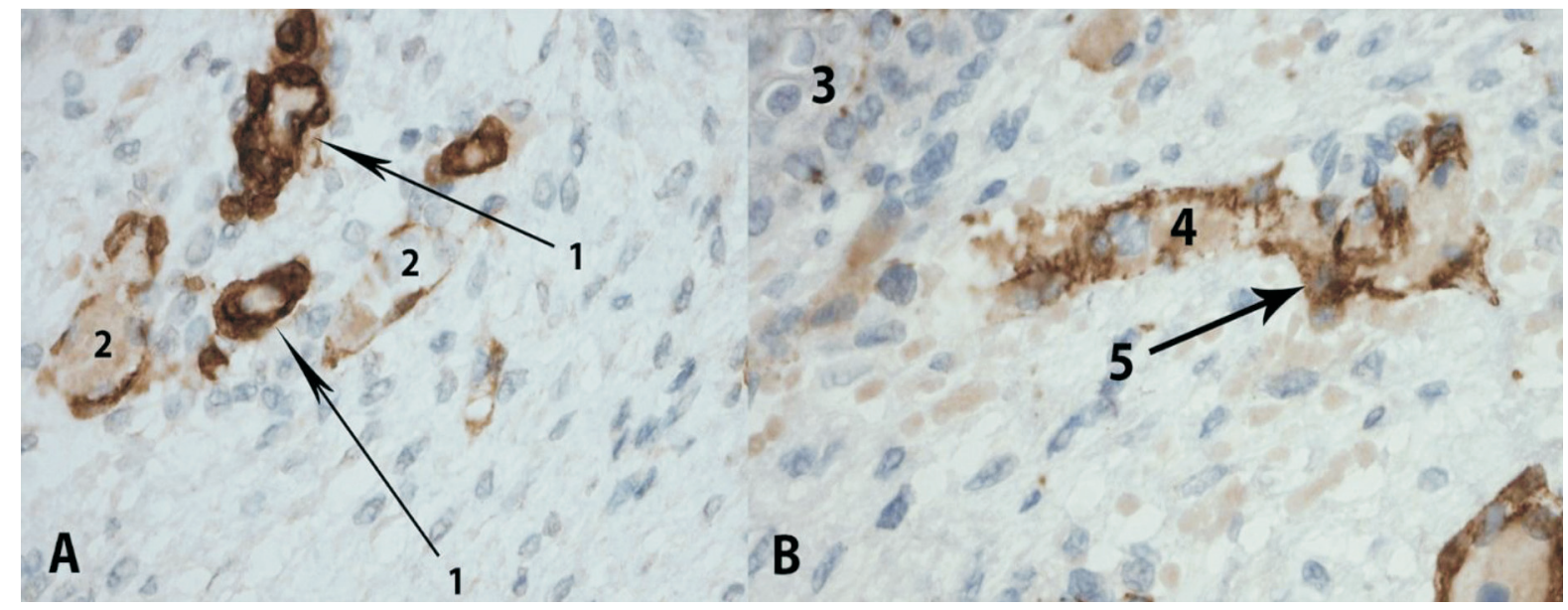

Fig. 5. The deep plexus of arterioles and venules and paired communicating vessels and postcapillary venule invested with pericytes at 17 weeks gestation. A: 1, arterioles; 2, venules. B: 3, epidermis; 4, postcapillary venule; 5, pericyte. SMA immunohistochemical staining, 20×.

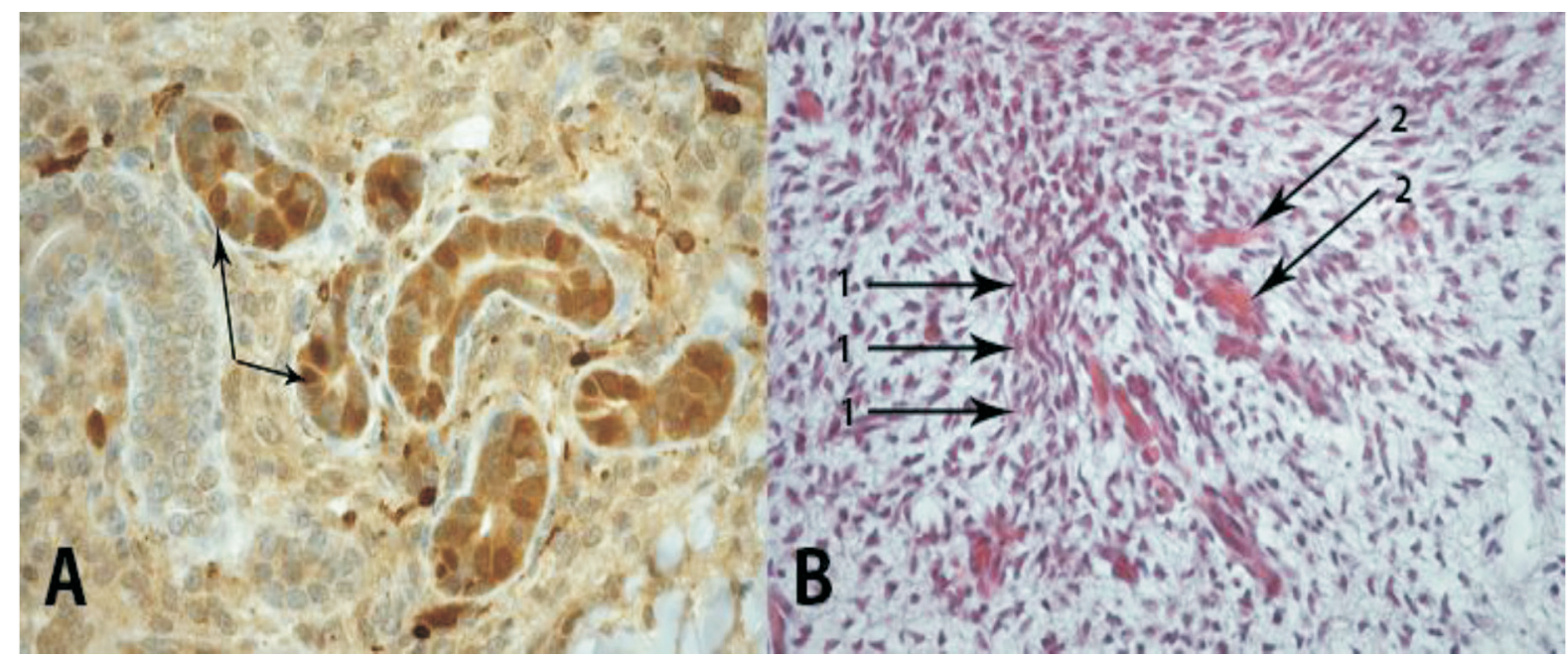

Fig. 6. A: At week 22, S-100 was visible in clear cells of the secretory portions of eccrine sweat glands (arrows). S-100 immunohistochemical staining, 20×. B: Cutaneous nerves and microvessels form a close association in the last phalanx of the finger at 13 weeks. 1 , nerve bundles; 2 , microvessels. Haematoxylin-eosin stain, 20x.

glands were detected by the $22^{\text {nd }}$ week (Fig. 6A). Concomitant with the development of hair follicles nail development began. As the development proceeded, the nail field becomes keratinised at 13 weeks and formed a so-called false nail. It was shown that by this time, dermal nerve bundle arborisation occurred in parallel with microvascular sprouting in the skin of fingertips (Fig. 6B). Our histological study showed that at the $5^{\text {th }}$ month gestation epidermis increased to five layers and was ready for keratinisation, which began after 20 weeks. By the $24^{\text {th }}$ week of gestation, cornified cells were present on almost all regions of the foetal skin.

\section{DISCUSSION}

During early pregnancy, placentation occurs in a relatively hypoxic environment, which is essential for appropriate embryonic development. Regional differences of cutaneous vascularity were detected in the presumptive dermis. Thus, the earliest specimens $\left(5^{\text {th }}\right.$ week) showed a very small number of blood capillaries in the presumptive dermis in all of the skin regions examined, except for the skin overlying the spinal cord. In this case, the presumptive dermis contains no blood vessels and nutritional needs of skin are probably met initially through the blood vessels of the presumptive leptomeninx. Endovascular trophoblast invades decidual spiral arteries and forms trophoblastic plugs. Our results are in agreement with those reported (Weiss et al., 2016) in that trophoblastic plugs obstruct maternal blood flow into the intervillous space and prevent flow until the end of first trimester of pregnancy (10-12 weeks). The plugs then loosen and permit continuous maternal blood flow into the intervillous space. It is likely that relative hypoxia exerts a critical role during early embryogenesis through prevention of oxidative stress (Burton et al., 1999). Oxidative stress can cause cellular damage, which can lead to cell death during histo- and organogenesis. Likewise, it is known that hypoxia promotes endothelial cell differentiation (PradoLopez et al., 2010). As pregnancy advances, to increase the delivery of blood to the intervillous space, extravillous trophoblast cells extend to both the decidual segment and one-third of the myometrial segment of the spiral artery, converting the arteries into wide-calibre vessels and increas- 
ing the delivery of blood to the intervillous space. The invading trophoblasts destroy arterial smooth muscle cells, replacing them with fibrinoid. Fibrinoid has been hypothesised to act as a sponge that absorbs potentially harmful maternal antibodies (Benirschke et al., 2012). There is at least one more attractive hypothesis, which proposes that mechanically supportive effects can be attributed to the various types of extravillous fibrinoid (Kretschmann, 1967).

Sufficient supply of oxygen and nutrients is essential for growth and for developing tissues and organs. Hence, development of the circulatory system is one of the main events during embryonic development. Intervillous blood flow increases at around 10-12 weeks of gestation and results in exposure of the placental barrier to increased oxygen tension (Jauniaux et al., 2003). It is worthwhile to note that during the first trimester, due to reduced uteroplacental blood flow, uterine glands provide histiotrophic nutrition to the embryo/foetus (Spencer, 2014). We confirmed the finding that extravillous trophoblast not only reaches the spiral arteries but also the uterine glands (Moser et al., 2015). It has been found that glandular epithelial cells were frequently replaced by endoglandular trophoblast opening the lumen of the glands toward the intervillous space. In addition to the migrating trophoblast cells, an admixture of $\mathrm{NK}$ cells was also found. Likewise, NK cells appeared in great abundance in subendothelium of decidual blood vessels. The location of the NK cells in close proximity to migrating extravillous trophoblasts seems to play a vital role in paternal MHC I detection and trophoblast invasion (Hanna et al., 2006; Madeja et al., 2011). This detection has functional consequences for the ability of NK cells to regulate decidual vessel formation as well as in the regulation in maternal vascular adaptation to pregnancy (Lima et al., 2014). Our observations suggest that HEV-like vessels mediate NK cell recruitment to the decidua.

The beating embryonic heart begins to pump exclusively nucleated erythrocytes from the yolk sac throughout the villus circulation by the end of the $4^{\text {th }}$ week of gestation. By 11 weeks, most RBC in the placental blood vessels were enucleated. Oxygen consumption is relatively low during the embryonic period (until about eight weeks) whilst the foetal period exhibits much higher oxygen consumption. This stage is characterised by exponential growth of the foetus. It was shown that the most rapid change in the rate of loss of nuclei by RBC occurred in foetuses during the $9^{\text {th }}$ week of development (Lin, 1960). Non-nucleated $\mathrm{RBC}$ are regarded as a particularly efficient adaptation to increase oxygen carrying potential. Immature intermediate villi of the early placenta showed characteristic reticular stroma with Hofbauer cells and sparse, centrally located vessels. Villous macrophages (Hofbauer cells) were numerous throughout the second trimester. The findings reported here confirm earlier observations focused on similar problems (Tang et al., 2011). It is believed that Hofbauer cells play an important role not only in the proliferation and differentiation of villous trophoblast and in remodelling of the mesenchymal core, but also in the promotion of angiogenesis (Loegl et al., 2016). During the second trimester of gestation, the mesenchymal core of the villi becomes denser, and villous blood vessels appear to be much closer to the syncytiotrophoblast. At the same time, some cytotrophoblast cells disappear and the first vasculosyncytial membranes start to develop. Villous branching consistent with adaptation to improve placental diffusing capacity was also observed. As it was shown previously, toward term, the placental barrier becomes very thin (Castellucci et al., 1990). The skin is the largest organ in the body and its development mainly depends on oxygen tension in the foetal blood and on the level of vascularisation of the dermis (Johnson and Holbrook, 1989). Due to the first wave of the remodelling of uterine arteries (endometrial spiral arteries) at 8 to 11 weeks, the maternal circulation fully inhabits the intervillous space of the placenta, causing a rise in oxygen tension (Hustin and Schaaps, 1987). These events coincide with the onset of certain key processes in skin development, such as the branching angiogenesis within the dermis and formation of PER and skin appendages. Simultaneously, the average number of non-nucleated RBC is elevated up to 98\% (Lin, 1960). From the results we conclude that actively growing epidermal derivatives, for example primordial hair follicles and apical ectodermal ridges, possess angiogenic properties. According to some observations, VEGF-1, produced by hair follicle, stimulates the growth of new capillaries from nearby blood vessels (Yano et al., 2001). The second wave of the remodelling of uterine arteries (myometrial segments) occurs at 16 to 18 weeks. These changes maximise the delivery of maternal blood to the intervillous space of the placenta, so that a sufficient blood supply through transformed arteries enables the transfer of enough nutrition and oxygen for the placenta. Concurrently mature intermediate placental villi are formed. They also have better vascularisation and the development of the vasculosyncytial membranes begins. By this period of time, dermal blood vessels form architecturally and functionally relevant vascular networks. We demonstrated that in the upper part of the dermis, the postcapillary venules are the predominant type of vessels. These vessels have extremely thin walls and can take over part of the normal function of the capillaries. The number of smallest exchange vessels of the foetal dermis is therefore greater than the number of blood capillaries and can provide the synthesis of the epithelial and dermal structural proteins (e.g. keratin and collagen), which is always associated with high energy and amino acid consumption (Halprin, 1966). Further, in a high oxygen environment the development of the main integumentary system parts will be completed by the differentiation of the sweat and sebaceous glands by week 22 .

Overall, during the first trimester, a thick villous barrier and decreased placental perfusion rate create a hypoxic state for embryogenesis. This is closely associated with poor vasculogenesis in presumptive dermis and epidermal stratification. Then the trophoblastic plugs will be loosen and permit continuous maternal blood flow into the intervillous space by $10-12^{\text {th }}$ weeks. It is of particular importance to note that the formation of the highly vascularised mature intermediate chorionic villi with the progressive reduction of trophoblast thickness are the histological basis for increased diffusion efficiency during the mid-trimester. This in turn 
mediates formation of stable dermal vascular networks and further development of the epidermis and its derivatives, suggesting that placental maturation precedes the final steps in foetal skin development.

\section{REFERENCES}

Baron, M. H., Isern, J., Fraser, S. T. (2012). The embryonic origins of erythropoiesis in mammals. Blood, 119 (21), 4828-4837.

Benirschke, K., Burton, G. J., Baergen, R. N. (2012). Pathology of the Human Placenta. $6^{\text {th }}$ edn. Springer, New York. 941 pp.

Burton, G. J., Jauniaux, E., Watson, A. L. (1999). Maternal arterial connections to the placental intervillous space during the first trimester of human pregnancy: The Boyd collection revisited. Amer. J. Obstet. Gynecol., 181, $718-724$.

Castellucci, M., Scheper, M., Scheffen, I., Celona, A., Kaufmann, P. (1990). The development of the human placental villous tree. Anat. Embryol., 181 (2), 117-128.

Chen, J. Z., Sheehan, P. M., Brennecke, S. P., Keogh, R. J. (2012). Vessel remodelling, pregnancy hormones and extravillous trophoblast function. Mol. Cell. Endocrinol., 349 (2), 138-144.

Coolen, N. A., Schouten, K. C., Middelkoop, E., Ulrich, M. M. (2010). Comparison between human fetal and adult skin. Arch. Dermat. Res., 302 (1), 47-55.

Fraser, R., Whitley, G. S., Thilaganathan, B., Cartwright, J. E. (2015). Decidual natural killer cells regulate vessel stability: Implications for impaired spiral artery remodelling. J. Reprod. Immunol., 110, 54-60.

Gunin, A. G., Petrov, V. V., Vasil'eva, O. V., Golubtsova, N. N. (2014). Blood vessels in human dermis during aging. Adv. Gerontol., 27 (1), $54-61$.

Halprin, K. M. (1966). The energy required for keratin synthesis. Brit. J. Dermat., 78, 541-543.

Hanna, J., Goldman-Wohl, D., Hamani, Y., Avraham, I., Greenfield, C., Natanson-Yaron, S., Prus, D., Cohen-Daniel, L., Arnon, T. I., Manaster, I., Gazit, R., Yutkin, V., Benharroch, D., Porgador, A., Keshet, E., Yagel, S., Mandelboim, O. (2006). Decidual NK cells regulate key developmental processes at the human fetal-maternal interface. Nat. Med., 12, 1065-1074.

Huppertz, B., Gauster, M., Orendi, K., König, J., Moser, G. (2009). Oxygen as modulator of trophoblast invasion. J. Anat., 215 (1), 14-20.

Hustin, J., Schaaps, J. P. (1987). Echographic [corrected] and anatomic studies of the maternotrophoblastic border during the first trimester of pregnancy. Amer. J. Obstet. Gynecol., 157 (1), 162-168.

Jauniaux, E., Gulbis, B., Burton, G. J. (2003). The human first trimester gestational sac limits rather than facilitates oxygen transfer to the foetus: A review. Placenta, Suppl. A, S86-S93.
Johnson, C. L., Holbrook, K. A. (1989). Development of human embryonic and fetal dermal vasculature. J. Invest. Dermatol., 93 (2), 10S-17S.

Kretschmann, H. J. (1967). About the fine structure of subchorial placental fibrin in comparison with blood fibrin. Acta Anat. (Basel), 66 (3), 339-364.

Lima, P. D., Zhang, J., Dunk, C., Lye, S. J., Croy, B. A. (2014). Leukocyte driven-decidual angiogenesis in early pregnancy. Cell. Mol. Immunol., 11, 522-537.

Lin Cheng Mu (1960). On the loss of nuclei of the red blood cells of Japanese embryos. Juntendo Med. J., 6, 609-611.

Loegl, J., Hiden, U., Nussbaumer, E., Schliefsteiner, C., Cvitic, S., Lang, I., Wadsack, C., Huppertz, B., Desoye, G. (2016). Hofbauer cells of M2a, $\mathrm{M} 2 \mathrm{~b}$ and M2c polarization may regulate feto-placental angiogenesis. $R \boldsymbol{e}$ production, 152 (5), 447-455.

Martin, R. J., Fanaroff, A. A., Walsh, M. C. (2014). Fanaroff and Martin's neonatal-perinatal medicine diseases of the fetus and infant. $10^{\text {th }}$ edn. Saunders, Philadelphia. 2024 pp.

Madeja, Z., Yadi, H., Apps, R., Boulenouar, S., Roper, S. J., Gardner, L., Moffett, A., Colucci, F., Hemberger, M. (2011). Paternal MHC expression on mouse trophoblast affects uterine vascularization and fetal growth Proc. Natl. Acad. Sci. USA, 108 (10), 4012-4017.

Moser, G., Weiss, G., Gauster, M., Sundl, M., Huppertz, B. (2015). Evidence from the very beginning: Endoglandular trophoblasts penetrate and replace uterine glands in situ and in vitro. Hum. Reprod., 30 (12), 2747-2757.

McKenney, J. K., Weiss, S. W., Folpe, A. L. (2001). CD31 expression in intratumoral macrophages: A potential diagnostic pitfall. Amer. J. Surg. Pathol., 25 (9), 1167-1173.

Prado-Lopez, S., Conesa, A., Arminán, A., Martínez-Losa, M., EscobedoLucea, C., Gandia, C., Tarazona, S., Melguizo, D., Blesa, D., Montaner, D., Sanz-González, S., Sepúlveda, P., Götz, S., O'Connor, J. E., Moreno, R., Dopazo, J., Burks, D. J., Stojkovic, M. (2010). Hypoxia promotes efficient differentiation of human embryonic stem cells to functional endothelium. Stem Cells, 28, 407-418.

Spencer, T. E. (2014). Biological roles of uterine glands in pregnancy. Semin. Reprod. Med., 32 (5), 346-357.

Stanek, J. (2013). Hypoxic patterns of placental injury: A review. Arch. Pathol. Labor. Med., 137, (5), 706-720.

Tang, Z., Abrahams, V. M., Mor, G., Guller, S. (2011). Placental Hofbauer cells and complications of pregnancy. Ann. NY Acad. Sci., 1221, 103-108.

Weiss, G., Sundl, M., Glasner, A., Huppertz, B., Moser, G. (2016). The trophoblast plug during early pregnancy: A deeper insight. Histochem. Cell. Biol., 146 (6), 749-756.

Yano, K., Brown, L. F., Detmar, M. (2001). Control of hair growth and follicle size by VEGF mediated angiogenesis. J. Clin. Invest., 107 (4), 409-417.

Received 5 February 2018

Accepted in the final form 2 October 2018

\section{PĀRMAIN̦AS PLACENTAS MORFOLOGIJĀ UN TO SAISTİBA AR EMBRIJA ĀDAS ATTĪSTĪBU}

Zīdītājiem histoǵenēze un organoǵenēze parasti norisinās hipoksiskā vidē. Skābekḷa difūzijas spēja savukārt atkarīga no difūzijas distances, ko ietekmē gan placentas barjeras biezums, gan audu vaskularitātes pakāpe. Tā kā epiderma ir avaskulāra, tās attīstība ir atkarīga no dermas asinsvadiem. Neraugoties uz plaši veiktajiem pētījumiem par embrioǵenēzi un uteroplacentāro cirkulāciju, pašreizējās zināšanas par to, kā placentas pārmaiņas grūtniecības laikā sekmē ādas attīstību, ir nepilnīgas. Šì pētījuma mērkị bija novērtēt korelāciju starp placentas barjeras strukturālajām izmainām un ādas attīstību, īpaši pievēršot uzmanību dermas angioǵenēzei. Pētījumā tika izmeklēti mikropreparāti no sešiem embrijiem un desmit augḷiem vecumā no 5. līdz 24. attīstības nedēlai, un 21 placentas audu mikropreparāti no 6 . līdz 40. grūtniecības nedēlai. Pētījumā izmantotās antivielas: S-100, SMA, CD31, CD34, AE1/AE3 (PCKT), CKRT7, CD 56 un hCG. Pirmā trimestra laikā mātes asins plūsma uz placentu sākotnēji ir ierobežota ar trofoblasta "korkiem". Deciduālo asinsvadu subendotēlijā tika pierādīti blīvi naturālo killeru šūnu infiltrāti, kas potenciāli stimulē apjomīgo angioǵenēzes procesu atlobenē. Pirmā trimestra beigās ap epidermas derivātiem veidojas jaunizveidotie asins kapilāri. Pētījumā apstiprināts, ka pirmajā grūtniecība trimestrī endometrija dziedzeri, kas spētu apgādāt embriju/augli ar uzturvielām, joprojām ir saistīti ar starpbārkstinu telpu. Otrā trimestra laikā placentas barjera pakāpeniski kḷūst plānāka, un, izzūdot endovaskulārajiem trofoblasta "korḳiem", tiek stabilizēta uteroplacentārā cirkulācija. Ādas derivātu, hipodermas taukaudu, nodalītas papilārās un retikulārās dermas izveides progresija un interfolikulārās epidermas keratinizācija otrajā trimestrī izteikti korelē ar dermas angioǵenēzi un placentas nobriešanu. 